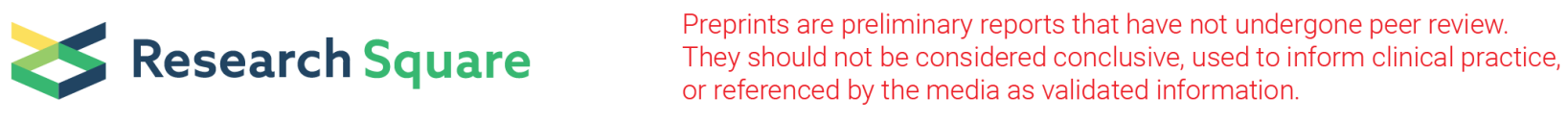

\title{
Stormwater Utility Fee Estimation Method for Individual Land Use Areas
}

jaehyun Yoo ( $\sim$ jhyoo0127@korea.kr)

NIER: National Institute of Environmental Research https://orcid.org/0000-0001-5097-5533

Jae-Hyun Yoo

NIER: National Institute of Environmental Research

Kye-Hyun Kim

Inha University

Ji-Yong Choi

Seoul National University

Chol-Young Lee

Korea Institute of Ocean Science and Technology

\section{Research Article}

Keywords: Stormwater Utility Fee, Impervious Surface Map, Impervious Surface Ratio Estimation Methodology, Nonpoint Source Management

Posted Date: May 13th, 2021

DOI: https://doi.org/10.21203/rs.3.rs-319295/v1

License: (c) (i) This work is licensed under a Creative Commons Attribution 4.0 International License. Read Full License 


\section{Abstract}

In South Korea, a reasonable rate system that can be domestically applied to calculate the sewage and stormwater separately from the domestic sewage fee system is needed. This study proposes a phased pricing scenario to separate sewage and stormwater in Bupyeong-gu, Incheon, and the rate changes are compared based on a simulated calculation of the stormwater utility fee. In this investigation, stormwater runoff cases from other countries and the current domestic system are analyzed. A stormwater utility fee introduction scenario is presented that considers the impervious surface area. Water and sewage usage statistics and hydrant spatial data were collected from the Incheon Metropolitan City Waterworks Authority, and the total amount of water and sewage fees from the land use area were calculated. The stormwater utility fee was calculated, and the rates of each step were compared.

The total sewage fee of Bupyeong-gu during 2014 was $21,685,446,578$ won and the phased stormwater utility fee was calculated, assuming that $40 \%$ represents the stormwater cost. The sewage fee for the residential area in phase 3 decreased by $0.77 \%$ compared to phase 1 . For the commercial areas, the sewage fee decreased by $36.87 \%$. Because the impervious surface ratio was high, the overall area contributing to the impervious surface area was small. In the industrial area, the sewage fee increased by $8.35 \%$. In the green area, the sewage fee increased by $37.46 \%$. The sewage fee for the apartment complexes decreased by $10.6 \%$. Finally, the possibility of estimating the actual stormwater utility fee is confirmed.

\section{Introduction}

Rapid urbanization is presently causing a variety of environmental problems in South Korea. In particular, having an increase in impervious surfaces has resulted in increasing nonpoint pollutants and the river environment is becoming polluted. This is because the impervious surfaces can increase the stormwater runoff, thereby carrying a variety of pollutants on the surface into the rivers or lakes (Kim et al. 1993; Kang et al. 2014).

Consequently, the development of low impact development (LID) and green stormwater infrastructure (GSI) technologies and the installation of the related facilities are increasing worldwide to reduce the non-point pollutants and to control the impervious surfaces (Dietz 2007; Che et al. 2014). Developed countries such as the US and Germany are enforcing the stormwater utility fee to raise funds for technology development and other related projects. The stormwater utility fee charges a fee to individual parcel owners by estimating the stormwater runoff in proportion to the impervious surface area of each parcel that is based on the "polluters pay principle," which is an environmental policy principle in most countries (Parikh et al. 2005; Roy et al. 2008; Crocket 2010; US EPA 2009; Bonnaffon 2011; Graham et al. 2011). In South Korea, studies on stormwater runoff management and fundraising have been conducted, such as "A Study on Introduction of Stormwater Pollution Rate System for Nonpoint Source Management" (MOE 2012) and "The Improvement Plans for Levying the Sewerage Fee Considering Land Cover and Stormwater Runoff" (Kim et al. 2015). However, South Korea still has many obstacles in terms of introducing and implementing stormwater utility fees and many technical and legal problems must be resolved. The stormwater utility fee is calculated based on the impervious surface area that is used to cover the cost by collecting more charges as the number of nonpoint source emissions increases, which takes into account the land cover condition. Hence, it is essential to secure spatial data with the statistics of the impervious surface area, which constitute a scientific basis.

Recently, the Ministry of Environment has suggested methods that use land cover maps, digital topographic maps, and aerial orthophotographs in order to create an impervious surface map to support the stormwater utility fee system (MOE, 2012). Lee (2018a, b) examined the methods of producing an impervious surface map as suggested by the MOE and verified the advantages and disadvantages of each method through a pilot production. As a result, a map production method that reclassifies the land cover map properties has the highest accuracy. Due to the production cycle of the land cover map, it is impossible to accurately and precisely classify the impervious surfaces that only uses single space data. Thus, to improve the spatial resolution and accuracy, Lee $(2018 a, b)$ suggested optimal methods to produce large-scale impervious surface maps by using aerial photographs, digital topographic maps, and road views on Internet portal sites. Then, a geographic information system (GIS)-based impervious surface ratio estimation method that uses a large-scale impervious surface map was defined, and the impervious surface ratio statistics were calculated for the land use and parcel units.

The impervious surface area is a measure that can indirectly represent the stormwater runoff amount and nonpoint pollutant generation, and it is a rational criterion for the stormwater utility fee. For this reason, most developed countries use the impervious surface areas as a criterion in order to charge a fee. The current domestic sewage fee system is unreasonable because the water users must pay the cost of treating the stormwater runoff. To solve this problem, a reasonable sewage fee system is required in South Korea that can calculate the stormwater treatment cost separately from the sewage fee.

Therefore, this study calculated the stormwater utility fee by simulating a GIS-based large-scale impervious surface map that was produced from a previous study. In addition, it is applied as a pilot to the land use areas on a large scale and to apartment complexes on a small scale. First, stormwater utility fee systems from the US and Germany are analyzed and the implications are derived, and the current domestic system is examined. The fee estimation scenario is established in three phases to separately calculate the sewage fee and stormwater runoff processing fee. Then, the monthly water and sewage usage in the study area and the hydrant spatial data in Shapefile format were collected. The properties of the water and sewage usage and the rates were input into the hydrant data, which overlapped with the serial cadastral map. The sewage fee was separately calculated from the water and sewage usage by using Microsoft Excel in accordance with the rate table and it was used as a basis for the stormwater utility fee estimation scenario. Finally, the changes in the stormwater utility fee were checked by applying it to each land use area and apartment complex while considering the number of households and the unit area size, and the results are discussed.

\section{Material And Methods}

\subsection{Study Area}


Bupyeong-gu, Incheon, South Korea, which has an area of $31.98 \mathrm{~km}^{2}$, was selected as the target area for this study (Fig. 1). Bupyeong-gu is a typical downtown area, which includes a variety of sectors such as residential areas, commercial areas, and industrial areas. Since 2009 , impervious surfaces have increased in this area along with the continuous promotion of several projects that include improving residential and urban environments (Lee et al. 2014). Furthermore, river flooding due to the localized heavy rains has caused the pollutants of urban sewage to flow into the Gulpo stream in Bupyeong-gu, which can lead to serious problems in terms of the generation and outflow of non-point pollutants. Thus, impervious surface and non-point pollution management are urgently needed in this area (Yang 2006).

Lee (2018b) created an optimal large-scale impervious surface map of Bupyeong-gu, Incheon, and determined that the area consisted of a pervious surface area of $11.43 \mathrm{~km}^{2}$, an impervious surface area of $20.5 \mathrm{~km}^{2}$, and a water system area of $0.15 \mathrm{~km}^{2}$. An impervious surface map of the land use area was drawn by overlapping the impervious surface map with the land use area map. The study area corresponds to an "urban area" in the classification of the properties of the land use area map. As shown in Fig. 2, the impervious surface ratio was $82.1 \%$ in the residential area, $91.7 \%$ in the commercial area, $94.1 \%$ in the industrial area, and $30 \%$ and in the green area. In particular, the impervious surface ratios of the residential, commercial, and industrial areas were higher than $80 \%$. This indicates that there is an urgent need to manage and improve the impervious surfaces.

\subsection{Analysis of the Domestic and Overseas Application Cases of the Stormwater Utility Fee}

\subsubsection{Application case of the stormwater utility fee in the US}

In the US, the federal government assigned the responsibility of managing the stormwater runoff that contains pollutants and sediments to the regional governments. As a result, this increased the stormwater runoff management cost of the regional governments, and they needed to establish a financing plan. The stormwater utility fee system was introduced in the 1960s, and in the beginning, the rates were charged based on the water usage. In the 1990 s, the Water Environment Federation issued the "User-Fee Funded Stormwater Utilities." As the emergence of GIS technology enabled the detailed measurement and management of the impervious surfaces, many municipalities changed the rating system to charging based on the impervious surface area. The collected fees are being used by the municipalities for the sewage pipe management cost as well as the facility investment, controlling the stormwater runoff, and treatment.

The city of Charlotte, which is an urban area, has a two-level rating system. Charlotte charges $\$ 5.18$ USD per month if the impervious surface area is $2,000 \mathrm{ft}{ }^{2}$ or less if it is a single family residence, and \$6.72 USD per month if it is larger than 2,000 $\mathrm{ft}^{2}$. Montgomery County's charging system has seven levels depending on the impervious surface area, and it is based on the equivalent residence unit (ERU). For apartment houses and nonresidential buildings, they charge $\$ 88.40$ USD per year per $1 \mathrm{ERU}\left(2,406 \mathrm{ft}^{2}\right)$ for the actual calculated impervious surface area (Table 1$)$. The city of Portland developed charges that are based on the average impervious surface area of $2,400 \mathrm{ft}^{2}$ for single- and two-family houses, and an average impervious surface area of $1,000 \mathrm{ft}^{2}$ for threeand four-family houses. For multi-family houses, commercial areas, and industrial areas that exceed them, the rates are charged based on the impervious surface area (Table 2). Washington D.C. uses a progressive rating system with six levels of impervious surface areas. The charging criterion for the residential area is $\$ 2.57$ USD per month per $1 \mathrm{ERU}$, and for nonresidential areas, the rates are charged in proportion to the actual impervious surface area (Fig. 3).

Table 1. Montgomery County's water quality protection fee charging system.

\begin{tabular}{|c|c|c|}
\hline Type & Division & Water quality protection fee (\$ USD) \\
\hline \multirow{7}{*}{$\begin{array}{l}\text { Independent detached house, connected detached house, and agricultural } \\
\text { facilities }\end{array}$} & Level $1\left(1,000 \mathrm{ft}^{2}\right.$ or less $)$ & 29.17 \\
\hline & Level $2\left(1,000-1,410 \mathrm{ft}^{2}\right)$ & 44.20 \\
\hline & Level $3\left(1,410-3,412 \mathrm{ft}^{2}\right)$ & 88.40 \\
\hline & Level $4\left(3,412-3,810 \mathrm{ft}^{2}\right)$ & 132.60 \\
\hline & Level $5\left(3,810-5,815 \mathrm{ft}^{2}\right)$ & 172.80 \\
\hline & Level $6\left(5,815-6,215 \mathrm{ft}^{2}\right)$ & 221.00 \\
\hline & Level 7 (larger than $6,215 \mathrm{ft}^{2}$ ) & 265.20 \\
\hline Apartment houses and nonresidential buildings & \multicolumn{2}{|c|}{ (Total impervious surface area/ERU) $\times \$ 88.40$} \\
\hline
\end{tabular}

Table 2. Portland's stormwater runoff fee. 


\begin{tabular}{|c|c|c|c|c|}
\hline Area & Division & & Stormwater runoff rate (S USD) & $\begin{array}{l}\text { Monthly average fee }(\$ \\
\text { USD) }\end{array}$ \\
\hline \multirow[t]{6}{*}{ Residential area } & \multirow[t]{2}{*}{$\begin{array}{l}\text { Single family and two-family } \\
\text { houses }\end{array}$} & $\begin{array}{l}\text { Off- } \\
\text { site }\end{array}$ & \$15.54 per month per family & \multirow[t]{2}{*}{$\$ 23.90$} \\
\hline & & $\begin{array}{l}\text { On- } \\
\text { site }\end{array}$ & $\$ 8.36$ per month per family & \\
\hline & \multirow[t]{2}{*}{$\begin{array}{l}\text { Three- and } \\
\text { four-family houses }\end{array}$} & $\begin{array}{l}\text { Off- } \\
\text { site }\end{array}$ & $\$ 6.47$ per month per family & \multirow[t]{2}{*}{$\$ 9.96$} \\
\hline & & $\begin{array}{l}\text { On- } \\
\text { site }\end{array}$ & $\$ 3.49$ per month per family & \\
\hline & \multirow[t]{2}{*}{ Five or more family houses } & $\begin{array}{l}\text { Off- } \\
\text { site }\end{array}$ & $\begin{array}{l}\$ 6.47 \text { per month per } 1,000 \mathrm{ft}^{2} \text { for the impervious } \\
\text { surface area }\end{array}$ & \multirow[t]{2}{*}{$\$ 9.96 / 1,000 \mathrm{ft}^{2}$} \\
\hline & & $\begin{array}{l}\text { On- } \\
\text { site }\end{array}$ & $\begin{array}{l}\$ 3.49 \text { per month per } 1,000 \mathrm{ft}^{2} \text { for the impervious } \\
\text { surface area }\end{array}$ & \\
\hline \multirow[t]{2}{*}{$\begin{array}{l}\text { Nonresidential } \\
\text { area * }\end{array}$} & Off-site & & $\begin{array}{l}\$ 6.86 \text { per month per } 1,000 \mathrm{ft}^{2} \text { for the impervious } \\
\text { surface area }\end{array}$ & \multirow[t]{2}{*}{$\$ 10.55 / 1,000 \mathrm{ft}^{2}$} \\
\hline & On-site & & $\begin{array}{l}\$ 3.69 \text { per month per } 1,000 \mathrm{ft}^{2} \text { for the impervious } \\
\text { surface area }\end{array}$ & \\
\hline
\end{tabular}

*The stormwater runoff fee is separately charged between on-site (private property) and off-site (right to use public facility).

As a result, most municipalities charge a stormwater utility fee based on the impervious surface area of each parcel, and the imposition criterion was changed from the parcel area or the water usage to the impervious surface.

When comparing the impervious surface area, the representative value (e.g., ERU) of the impervious surface area was set for each municipality and the fees were calculated accordingly. For the residential areas, some municipalities applied the same rate of 1 ERU to every parcel while considering the size and management cost of the city. Meanwhile, other municipalities applied different rates by setting different levels of the impervious surface area.

\subsubsection{Application case of the stormwater utility fee in Germany}

In 1985, the Federal Administrative Court and Local High Courts of Germany declared that charging sewage fees based on the water usage was problematic in terms of fairness (Kwon and Hur 2010). The Federal Administrative Court of Germany ruled that in order to improve the legal fairness of the fees that are based on the polluters pay principle, the sewage fees must be collected separately for the stormwater runoff processing fees and general sewage fees. Consequently, the municipalities changed their fee collection system and established a legal basis for urging the utilization and infiltration of stormwater. In addition, they reflected the specific matters for the application of the separate calculation method for the sewage ordinance in accordance with the circumstances of the city.

In the case of Berlin, the water bill is divided into a basic fee and usage-based fee, and the sewage fee is divided into wastewater, stormwater, manure, and manure sludge fees. The wastewater fee is charged in proportion to the water discharge (water usage) in addition to the basic fee, whereas the stormwater fee is charged based on the impervious surface area (Table 3). Berlin changed to a sewage separate fee system in 2000 and they charged 1.897 Euros per $1 \mathrm{~m}^{2}$ for the impervious surface in addition to the sewage fee.

Table 3. Berlin's water and sewage fee structure (Berlin, Germany).

\begin{tabular}{|c|c|c|c|}
\hline \multicolumn{3}{|l|}{ Division } & Note \\
\hline \multirow{2}{*}{$\begin{array}{l}\text { Water } \\
\text { fee }\end{array}$} & \multicolumn{2}{|c|}{ Usage-based fee } & Charged according to the actual water usage \\
\hline & \multicolumn{2}{|l|}{ Basic fee } & Charged according to the caliber of the water meter \\
\hline \multirow[t]{5}{*}{$\begin{array}{l}\text { Sewage } \\
\text { fee }\end{array}$} & \multirow[t]{2}{*}{$\begin{array}{l}\text { Wastewater } \\
\text { fee }\end{array}$} & $\begin{array}{l}\text { Discharge- } \\
\text { based fee }\end{array}$ & Charged according to the actual water usage \\
\hline & & Basic fee & Charged according to the caliber of the water meter \\
\hline & \multicolumn{2}{|c|}{ Stormwater fee } & $\begin{array}{l}\text { Charged in proportion to the area of the impervious surface in which the stormwater flows into public } \\
\left.\text { sewage facilities ( } 1.897 \text { Euros } / \mathrm{m}^{2}\right)\end{array}$ \\
\hline & \multicolumn{2}{|l|}{ Manure fee } & - \\
\hline & \multicolumn{2}{|c|}{ Manure sludge fee } & - \\
\hline
\end{tabular}


In general, the stormwater utility fee is charged based on the flat rate, impervious surface area, development density, and the generation of stormwater runoff. The flat rate charges the same fee for every household; however, it is difficult to apply the same rate to areas that have different discharge amounts. The stormwater runoff generation creates high administrative costs for the monitoring and measurements. The development density method charges the fee according to the ratio of the impervious surface area for the total land. However, it is difficult to implement this in comparison to the ERU method because the pervious and impervious surfaces must be considered. In contrast, the method of charging the fee that is based on the impervious surface area of each parcel is mainly used in developed countries because it is an indirect indicator of the stormwater runoff and generation of non-point pollutants. Furthermore, the specific implementation methods of the system, such as the charging and collecting methods, did not differ significantly between the two countries (Table 4). Therefore, the optimal large-scale impervious surface map by Lee (2018a) can be used as the basic data for calculating the stormwater utility fee. If the impervious surface area is applied based on the stormwater utility fee, the fee decreases slightly for users with a small impervious surface area such as detached houses; however, it increases significantly for users that have a large impervious surface area, such as commercial buildings, which is fair. The stormwater utility fee system is advantageous in terms of being able to cover the impervious surface management cost of private properties that can cause stormwater runoff that flows into public sewage treatment facilities. Like the US and Germany, which have similar problems, South Korea should also prepare related management funds by charging fees that are based on the impervious surface of each parcel.

Table 4. Comparison of the funding characteristics for the stormwater utility fee between the US and Germany.

\begin{tabular}{|lll|}
\hline Division & US (stormwater utility fee) & Germany (regenwassergebühr) \\
\hline Background & $\begin{array}{l}\text { - Deterioration of the water quality by the stormwater } \\
\text { runoff } \\
\text { - Reinforced stormwater runoff regulation of the } \\
\text { environmental protection agency (EPA) and stable } \\
\text { stormwater management funding }\end{array}$ & $\begin{array}{l}\text { - The rate system was reformed according to the ruling of the Federal } \\
\text { Administrative Court that the existing stormwater and wastewater } \\
\text { combined rate system is not fair. }\end{array}$ \\
\hline Charging criteria & - Stormwater fee is charged based on the polluters pay principle. \\
& - Charged in proportion to the past water usage. \\
& - Charged in proportion to the impervious surface area of each parcel \\
\hline Charging method & - Municipalities use different methods for the fee calculation \\
\hline $\begin{array}{l}\text { Charging effect } \\
\text { based on the } \\
\text { impervious surface }\end{array}$ & - - Fees decreased for small detached houses and apartment houses \\
\hline
\end{tabular}

\subsubsection{Related systems in South Korea}

In South Korea, the sewage fees are specified by the ordinances of the local governments in accordance with Article 61 (e.g., Charge on Burden-Causing Entities) and Article 65 (Use Fees, etc.) of the Sewerage Act, and the local government's sewage fees are different. The fee calculation is specified according to the rules of the Ministry of the Interior and Safety and it is collected based on the rate table. The targets of the fee are classified into the household, public bathhouses, operations, and businesses, and different rates for the monthly usage are applied to them (MOE 2018). In South Korea, the operation costs of the sewage treatment plants and wastewater pump stations are classified as wastewater treatment costs. Meanwhile, the operation costs for the stormwater pipes and stormwater pump stations of the separate sewage pipes are classified as stormwater treatment costs. However, the cost for the combined sewage pipes is classified as the wastewater treatment cost even though the wastewater and stormwater flow together and they are not classified by the appropriate ratio of the wastewater and stormwater. Thus, it appears on the surface that the domestic sewage fee system does not include stormwater; however, it can be internally interpreted that it includes stormwater. It has an unreasonable structure in which the water applications (including groundwater) generally pay for the stormwater treatment costs. To improve this unreasonable structure, a reasonable sewage fee system that separates wastewater and stormwater fees and replaces the stormwater fee with a stormwater utility fee is required.

In the "2050 Sewerage Vision Public Hearing" that was held in 2012, a "stormwater utility fee" design method for stormwater management funding was presented. The targets of the stormwater utility fee were land owners that have their land hydraulically connected to public stormwater (wastewater) pipes. It was suggested that the standard cost covers the cost that is required for stormwater management such as conduit and stormwater treatment, and the method of imposition is different according to the land cover, which is a factor that influences the stormwater discharge. To introduce the stormwater utility fee, a method of amending the current law should be considered because enacting a new law can result in large resistance. In addition, the stormwater utility fee should be applied in a phased manner, and it must be preceded by the people's empathy and understanding. In 2012, at the "policy discussion meeting for introducing a rainwater tax in Seoul," there was a case of serious opposition such as a resistance to tax increases and transferring the responsibility to create an impervious surface to the citizens. To enhance the people's acceptance of the stormwater utility fee system, phased applications that are based on South Korea's current rate system must be considered. The separate calculation and settlement of the stormwater utility fee must be implemented step by step. This can be achieved by separating the sewage fee into wastewater and stormwater in the beginning and later switching to the fee calculation while considering the impervious surface area of each parcel.

When the fee is linked with the stormwater management, the fee must be calculated while considering the impervious surface area that is based on the current land cover information. Therefore, a concrete scenario is required, which consists of the following three phases. In phase 1 , the current sewage fee is simply 
separated into wastewater and stormwater. In phase 2, the impervious surface ratio based on the land use area is applied. In phase 3 , the fee is specifically calculated for the individual parcels.

\subsection{Simulated calculation of the stormwater utility fee for the study area}

According to Lee (2018b), the total area of all the apartment complexes in Bupyeong-gu was approximately $3.65 \mathrm{~km}^{2}$, and the total impervious surface ratio was $75.8 \%$. When considering the 189 complexes, 43 had no previous surface with a $100 \%$ impervious surface ratio. Although some complexes have flower gardens, they were classified as impervious surfaces if they did not play the role of a pervious surface. When considering the apartment complexes in Bupyeong-gu, the lowest impervious surface ratio was $57.1 \%$, and the highest impervious surface ratio was $92.9 \%$, which excludes 43 complexes with a $100 \%$ impervious surface ratio. According to the building ordinance of Incheon, parcels with an area of 2,000 $\mathrm{m}^{2}$ or larger must include a $15 \%$ landscape area; however, some apartment complexes do not comply with this rule. Therefore, impervious surfaces need to be actively managed in apartment complexes with an impervious surface ratio that is $85 \%$ for higher.

Consequently, for the simulated calculation of the stormwater utility fee in the study area (Bupyeong-gu, Incheon), the sewage fee was separated into wastewater and stormwater fees, and the fee calculation that considered the impervious surface area was presented in phases. These calculated phased fees were applied to a large apartment complex while considering the number of households and the unit area type in order to check the changes in the stormwater utility fee. Bupyeong-gu, Incheon is currently charging wastewater and stormwater management costs together as a certain ratio of the water fee in proportion to the water usage. Therefore, the monthly water usage statistics of Bupyeong-gu, Incheon were collected, and the fees were determined by calculating the actual sewage fee.

To change the fee system to a fee linked with stormwater management, the fee must be calculated while considering the impervious surface area that is based on the land cover status. Hence, a scenario is required, which consists of the following three phases. In phase 1, the current sewage fee is simply separated into wastewater and stormwater. In phase 2 , the impervious surface ratio that is based on the land use area is applied. In phase 3 , the fee is specifically calculated for the individual parcels. The phased hypothetical scenario was established and the fees were calculated by performing a simulation to check the change in the the stormwater utility fee based on land use area (Fig. 4).

\subsubsection{Collecting water usage statistics and data processing}

When considering the data to calculate the stormwater utility fee, the statistics for the monthly water and sewage usage and the fees in 2014 , along with the hydrant spatial data for the Shapefile format, were gathered from the Incheon Metropolitan City Waterworks Authority. The water and sewage fees were calculated by converting the water and sewage rate table into a function using Microsoft Excel. These were used as the basis of the stormwater utility fee estimation scenario. It was determined that there were missing data for the monthly water and sewage usage along with the fees due to the closure and movement of the hydrants. In this case, the business category was estimated and the aperture size was calculated in reverse based on the fee, and the related information was added. The improvement results were converted to space data by combining them with the hydrant spatial data. In addition, the properties of the water and sewage usage and fees were inputted into the serial cadastral map, which overlapped with the hydrant spatial data. In some cases, one hydrant was used by multiple parcels, in which the aerial orthophotograph and digital topographic map were checked. They were joined and converted to a single parcel on the serial cadastral map by using the "merge" function of ArcGIS 10.2. The impervious surface ratio of the joined parcels was calculated again, and the water and sewage usages and fees were inputted into the properties of the serial cadastral map. Finally, the water and sewage fees resulted in a calculation of 68,457 results in Bupyeong-gu.

\subsubsection{Simulated calculation scenario for the stormwater utility fee}

In the phase 1 scenario, when considering the people's acceptance, the current sewage fee was divided into the wastewater and stormwater fees by using a simple ratio. When the sewage fee is collected, the stormwater cost is charged as a stormwater utility fee. In this study, a general distribution ratio of $6: 4$ was applied. Table 5 shows the differences in the charging method between the current sewage fee and the phase 1 scenario. Meanwhile, in the phase 1 scenario, the fee is calculated irrespective of the impervious surface ratio for each land use area and parcel. However, the total amount of the stormwater utility fee in Phase 1 was used as the reference amount for the fee distribution in phases 2 and 3.

Table 5. Differences in the charging method between the current sewage fee and the fee of the phase 1 scenario.

\begin{tabular}{|lll|}
\hline Division & Current & Phase 1 scenario \\
\hline $\begin{array}{l}\text { Payment notification } \\
\text { method }\end{array}$ & - Sewage fee & - The existing total amount is separated as the sewage fee and stormwater utility fee. \\
& $\begin{array}{l}\text { (e.g., sewage fee of } 8000 \\
\text { won) }\end{array}$ & $\begin{array}{l}(\text { e.g., sewage (wastewater) fee of 4,800 won (60\%), stormwater utility fee of 3,200 won } \\
(40 \%)\end{array}$ \\
\hline
\end{tabular}

As for phase 2, Lee (2018b) reported that South Korean cities have a high impervious surface ratio for each land use area, and there is no significant difference between the parcels in the land use area. Furthermore, unlike other countries, South Korea has many apartment complexes, and most of the detached house districts have a high impervious surface ratio. When considering these facts, the fee by the land use area was applied in phase 2 while considering the administrative convenience. The stormwater utility fee in the total sewage fee is calculated by distributing the fee in consideration of the average impervious surface ratio for each land use area. The concrete fee calculation method is presented as follows.

Page 6/16 
For the "total stormwater utility fee" in Eq. (1), the total stormwater utility fee that is calculated in the phase 1 scenario (corresponding to $40 \%$ of the total sewage fee) is used. For the impervious surface area that is based on the land use area, the calculation result from the impervious surface map was produced from a previous study (Lee 2018a).

The phase 3 scenario is similar in comparison to the developed countries and it can be implemented after the fee for the stormwater runoff management is stabilized. The impervious surface ratio is calculated for the individual parcels, and the fee is determined in proportion to the calculated impervious surface ratio. For the total sewage fee, the stormwater utility fee is distributed and the contribution rate of each parcel is considered. The concrete fee calculation method is expressed as follows.

Unit fee $=$ Total stormwater runoff fee $/$ Total impervious surface area

Fee by parcel $=$ Impervious surface area for an individual parcel $\times$ Unit fee

The phase 3 scenario can be used to calculate the impervious surface ratio of the individual parcels irrespective of the land use area. It is fair and reasonable because the contribution to the stormwater runoff management can be applied quantitatively.

\section{Results \& Discussion}

\subsection{Water and sewage usage and the fee calculation based on the land use area}

The water and sewage usage and the fees by the land use area were calculated based on the serial cadastral map. The total water usage, total sewage usage, and total water and sewage fees for Bupyeong-gu from January to December 2014 were 56,493,980 $\mathrm{m}^{3}, 55,882,048 \mathrm{~m}^{3}$, and 75,790,569,320 won, respectively. The water and sewage usage and fees were the highest in the residential areas and the lowest in the green areas (Table 6). When considering the total water and sewage fees, the sewage fee was calculated as $21,685,446,578$ won, and it was used as the reference amount for the stormwater utility fee scenario.

Table 6. Monthly water and sewage usages and fees based on the land use area in Bupyeong-gu in 2014.

(Unit: $1,000 \mathrm{~m}^{3}$, million won; 1,100 won $=\$ 1$ USD)

\begin{tabular}{|c|c|c|c|c|c|c|c|c|c|c|c|c|c|c|c|}
\hline Division & Land Use Are & & Total & Jan & Feb & Mar & Apr & May & Jun & Jul & Aug & Sep & Oct & Nov & Dec \\
\hline \multirow[t]{5}{*}{ Water Usage } & Total & & 56,494 & 4,607 & 4,729 & 4,481 & 4,303 & 4,610 & 4,610 & 4,921 & 4,899 & 5,098 & 4,925 & 4,636 & 4,675 \\
\hline & Residential & Sum & 36,673 & 2,960 & 3,014 & 2,888 & 2,774 & 3,001 & 3,001 & 3,206 & 3,229 & 3,337 & 3,219 & 3,023 & 3,022 \\
\hline & Commercial & Sum & 6,937 & 552 & 586 & 559 & 519 & 558 & 558 & 599 & 596 & 629 & 616 & 575 & 591 \\
\hline & Industrial & Sum & 7,325 & 633 & 660 & 599 & 577 & 590 & 590 & 623 & 598 & 649 & 615 & 592 & 600 \\
\hline & Green & Sum & 5,558 & 462 & 469 & 436 & 434 & 461 & 461 & 493 & 476 & 483 & 476 & 445 & 462 \\
\hline \multirow{5}{*}{$\begin{array}{l}\text { Sewage } \\
\text { Usage }\end{array}$} & Total & & 55,882 & 4,559 & 4,646 & 4,409 & 4,262 & 4,532 & 4,582 & 4,883 & 4,859 & 5,041 & 4,880 & 4,595 & 4,635 \\
\hline & Residential & Sum & 39,748 & 3,238 & 3,255 & 3,122 & 3,030 & 3,215 & 3,271 & 3,490 & 3,490 & 3,594 & 3,471 & 3,275 & 3,296 \\
\hline & Commercial & Sum & 8,120 & 649 & 681 & 641 & 609 & 651 & 659 & 704 & 697 & 736 & 722 & 677 & 692 \\
\hline & Industrial & Sum & 6,265 & 529 & 556 & 506 & 486 & 518 & 503 & 535 & 525 & 557 & 536 & 507 & 509 \\
\hline & Green & Sum & 1,749 & 143 & 154 & 141 & 136 & 148 & 148 & 155 & 147 & 153 & 152 & 136 & 138 \\
\hline \multirow{5}{*}{$\begin{array}{l}\text { Water and } \\
\text { Sewage } \\
\text { Fees }\end{array}$} & Total & & 75,791 & 6,297 & 6,464 & 6,059 & 5,728 & 5,979 & 6,169 & 6,616 & 6,565 & 6,861 & 6,603 & 6,189 & 6,261 \\
\hline & Residential & Sum & 45,021 & 3,682 & 3,740 & 3,549 & 3,373 & 3,547 & 3,686 & 3,961 & 3,983 & 4,125 & 3,963 & 3,703 & 3,709 \\
\hline & Commercial & Sum & 12,193 & 982 & 1,041 & 974 & 914 & 947 & 986 & 1,056 & 1,052 & 1,113 & 1,081 & 1,012 & 1,035 \\
\hline & Industrial & Sum & 10,950 & 981 & 1,030 & 929 & 849 & 861 & 867 & 920 & 881 & 963 & 911 & 873 & 885 \\
\hline & Green & Sum & 7,626 & 651 & 653 & 607 & 591 & 624 & 630 & 679 & 649 & 661 & 649 & 602 & 631 \\
\hline
\end{tabular}

\subsection{The fee application result based on the land use area scenario}

The calculation results for the sewage fee and stormwater utility fee based on the land use area for phases 1 to 3 are summarized in Table 7 . In this table, the "total" means the total sewage fee, which includes the wastewater and stormwater fees, "wastewater" represents the wastewater treatment fee, and "stormwater" denotes the stormwater utility fee. The annual total sewage fee remained the same at 21,685,446,578 won (\$19.7 million USD) in every scenario, 
and the sewage fee was determined by changing the ratio of the stormwater utility fee in each scenario. The results were then compared (Table 8 ). As it moved from phase 1 to phase 2, the stormwater utility fee of Bupyeong-gu, Incheon decreased in the commercial area; however, it increased in the residential, industrial, and green areas. Then, as it moved from phase 2 to phase 3, the stormwater utility fee of Bupyeong-gu, Incheon decreased in the residential and commercial areas, but it increased in other areas.

The sewage fee of the residential area decreased by $0.77 \%$ in phase 3 in comparison to phase 1 . Since there are many apartment complexes in South Korea, the fee is expected to decrease when considering the number of households and the unit area type. When considering commercial areas, the impervious surface ratio is high, but as a whole, the area contributing to the impervious surface is small. Thus, the stormwater runoff fee decreased by $36.87 \%$. Since the occupied impervious surface area is not large in comparison to the water usage, the stormwater fee decreased when it is proportional to the impervious surface area. In the industrial area, the water usage is similar to that of the commercial area; however, the total impervious surface area is 1.9 times larger than that of the commercial area. As a result, the sewage fee increased by $8.35 \%$. In the green area, the water usage is small, but the total impervious surface area is large; thus, the sewage fee increased by $37.46 \%$. Moreover, there are many public facilities in addition to military facilities in the green area in Bupyeong-gu; hence, the stormwater runoff management burden increased.

Table 7. Calculation result of the sewage and stormwater fees according to the scenarios for phases 1 to 3.

(Unit: million won) 


\begin{tabular}{|c|c|c|c|c|c|c|c|c|c|c|c|c|c|c|c|}
\hline \multirow[t]{2}{*}{ Phase } & \multirow{2}{*}{\multicolumn{2}{|c|}{ By land use area }} & \multicolumn{13}{|c|}{ Monthly fees } \\
\hline & & & Total & Jan & Feb & Mar & Apr & May & Jun & Jul & Aug & Sep & Oct & Nov & Dec \\
\hline \multirow{15}{*}{$\begin{array}{l}\text { Phase } \\
1\end{array}$} & \multirow[t]{3}{*}{ Total } & Total & 21,685 & 1,820 & 1,876 & 1,770 & 1,675 & 1,854 & 1,752 & 1,818 & 1,873 & 1,846 & 1,853 & 1,760 & 1,791 \\
\hline & & Wastewater & 13,013 & 1,092 & 1,126 & 1,062 & 1,005 & 1,112 & 1,051 & 1,091 & 1,124 & 1,108 & 1,112 & 1,056 & 1,075 \\
\hline & & Stormwater & 8,675 & 728 & 750 & 708 & 670 & 742 & 701 & 727 & 749 & 738 & 741 & 704 & 716 \\
\hline & \multirow{3}{*}{$\begin{array}{l}\text { Residential } \\
\text { area }\end{array}$} & Total & 11,280 & 938 & 950 & 921 & 876 & 1,000 & 914 & 947 & 963 & 961 & 959 & 921 & 930 \\
\hline & & Wastewater & 6,768 & 563 & 570 & 553 & 526 & 600 & 548 & 568 & 578 & 577 & 575 & 553 & 558 \\
\hline & & Stormwater & 4,512 & 375 & 380 & 368 & 350 & 400 & 366 & 379 & 385 & 384 & 384 & 368 & 372 \\
\hline & \multirow{3}{*}{$\begin{array}{l}\text { Commercial } \\
\text { area }\end{array}$} & Total & 5,191 & 420 & 445 & 410 & 394 & 407 & 421 & 447 & 471 & 448 & 456 & 432 & 440 \\
\hline & & Wastewater & 3,115 & 252 & 267 & 246 & 236 & 244 & 253 & 268 & 283 & 269 & 274 & 259 & 264 \\
\hline & & Stormwater & 2,076 & 168 & 178 & 164 & 158 & 163 & 168 & 179 & 188 & 179 & 182 & 173 & 176 \\
\hline & \multirow{3}{*}{$\begin{array}{l}\text { Industrial } \\
\text { area }\end{array}$} & Total & 3,221 & 285 & 305 & 272 & 250 & 259 & 253 & 262 & 280 & 268 & 273 & 255 & 259 \\
\hline & & Wastewater & 1,933 & 171 & 183 & 163 & 150 & 155 & 152 & 157 & 168 & 161 & 164 & 153 & 155 \\
\hline & & Stormwater & 1,288 & 114 & 122 & 109 & 100 & 104 & 101 & 105 & 112 & 107 & 109 & 102 & 104 \\
\hline & \multirow[t]{3}{*}{ Green area } & Total & 1,996 & 177 & 176 & 167 & 155 & 188 & 164 & 162 & 159 & 169 & 165 & 152 & 162 \\
\hline & & Wastewater & 1,198 & 106 & 106 & 100 & 93 & 113 & 98 & 97 & 95 & 101 & 99 & 91 & 97 \\
\hline & & Stormwater & 798 & 71 & 70 & 67 & 62 & 75 & 66 & 65 & 64 & 68 & 66 & 61 & 65 \\
\hline \multirow{15}{*}{$\begin{array}{l}\text { Phase } \\
2\end{array}$} & \multirow[t]{3}{*}{ Total } & Total & 21,685 & 1,820 & 1,876 & 1,770 & 1,675 & 1,854 & 1,752 & 1,818 & 1,873 & 1,846 & 1,853 & 1,760 & 1,791 \\
\hline & & Wastewater & 13,013 & 1,092 & 1,126 & 1,062 & 1,005 & 1,112 & 1,051 & 1,091 & 1,124 & 1,108 & 1,112 & 1,056 & 1,075 \\
\hline & & Stormwater & 8,675 & 728 & 750 & 708 & 670 & 742 & 701 & 727 & 749 & 738 & 741 & 704 & 716 \\
\hline & \multirow{3}{*}{$\begin{array}{l}\text { Residential } \\
\text { area }\end{array}$} & Total & 11,607 & 968 & 988 & 949 & 900 & 1,013 & 939 & 973 & 996 & 990 & 988 & 946 & 958 \\
\hline & & Wastewater & 6,768 & 563 & 570 & 553 & 526 & 600 & 548 & 568 & 578 & 577 & 575 & 553 & 558 \\
\hline & & Stormwater & 4,839 & 405 & 418 & 396 & 374 & 413 & 391 & 405 & 418 & 413 & 413 & 393 & 400 \\
\hline & \multirow{3}{*}{$\begin{array}{l}\text { Commercial } \\
\text { area }\end{array}$} & Total & 3,902 & 318 & 335 & 310 & 297 & 311 & 317 & 334 & 351 & 336 & 341 & 323 & 329 \\
\hline & & Wastewater & 3,115 & 252 & 267 & 246 & 236 & 244 & 253 & 268 & 283 & 269 & 274 & 259 & 264 \\
\hline & & Stormwater & 787 & 66 & 68 & 64 & 61 & 67 & 64 & 66 & 68 & 67 & 67 & 64 & 65 \\
\hline & \multirow{3}{*}{$\begin{array}{l}\text { Industrial } \\
\text { area }\end{array}$} & Total & 3,409 & 295 & 311 & 284 & 264 & 281 & 271 & 281 & 295 & 287 & 290 & 272 & 277 \\
\hline & & Wastewater & 1,933 & 171 & 183 & 163 & 150 & 155 & 152 & 157 & 168 & 161 & 164 & 153 & 155 \\
\hline & & Stormwater & 1,476 & 124 & 128 & 121 & 114 & 126 & 119 & 124 & 127 & 126 & 126 & 119 & 122 \\
\hline & \multirow[t]{3}{*}{ Green area } & Total & 2,771 & 238 & 242 & 228 & 214 & 248 & 225 & 229 & 231 & 235 & 234 & 218 & 227 \\
\hline & & Wastewater & 1,198 & 106 & 106 & 100 & 93 & 113 & 98 & 97 & 95 & 101 & 99 & 91 & 97 \\
\hline & & Stormwater & 1,573 & 132 & 136 & 128 & 121 & 135 & 127 & 132 & 136 & 134 & 135 & 127 & 130 \\
\hline \multirow{12}{*}{$\begin{array}{l}\text { Phase } \\
3\end{array}$} & \multirow[t]{3}{*}{ Total } & Total & 21,685 & 1,820 & 1,876 & 1,770 & 1,675 & 1,854 & 1,752 & 1,818 & 1,873 & 1,846 & 1,853 & 1,760 & 1,791 \\
\hline & & Wastewater & 13,013 & 1,092 & 1,126 & 1,062 & 1,005 & 1,112 & 1,051 & 1,091 & 1,124 & 1,108 & 1,112 & 1,056 & 1,075 \\
\hline & & Stormwater & 8,675 & 728 & 750 & 708 & 670 & 742 & 701 & 727 & 749 & 738 & 741 & 704 & 716 \\
\hline & \multirow{3}{*}{$\begin{array}{l}\text { Residential } \\
\text { area }\end{array}$} & Total & 11,194 & 934 & 953 & 914 & 867 & 978 & 906 & 939 & 960 & 954 & 953 & 913 & 924 \\
\hline & & Wastewater & 6,768 & 563 & 570 & 553 & 526 & 600 & 548 & 568 & 578 & 577 & 575 & 553 & 558 \\
\hline & & Stormwater & 4,426 & 371 & 383 & 361 & 341 & 378 & 358 & 371 & 382 & 377 & 378 & 360 & 366 \\
\hline & \multirow{3}{*}{$\begin{array}{l}\text { Commercial } \\
\text { area }\end{array}$} & Total & 3,793 & 309 & 326 & 301 & 288 & 302 & 308 & 325 & 341 & 327 & 332 & 314 & 320 \\
\hline & & Wastewater & 3,115 & 252 & 267 & 246 & 236 & 244 & 253 & 268 & 283 & 269 & 274 & 259 & 264 \\
\hline & & Stormwater & 678 & 57 & 59 & 55 & 52 & 58 & 55 & 57 & 58 & 58 & 58 & 55 & 56 \\
\hline & Industrial & Total & 3,515 & 304 & 320 & 292 & 272 & 290 & 279 & 289 & 305 & 296 & 299 & 282 & 286 \\
\hline & & Wastewater & 1,933 & 171 & 183 & 163 & 150 & 155 & 152 & 157 & 168 & 161 & 164 & 153 & 155 \\
\hline & & Stormwater & 1,582 & 133 & 137 & 129 & 122 & 135 & 127 & 132 & 137 & 135 & 135 & 129 & 131 \\
\hline
\end{tabular}




\begin{tabular}{|c|c|c|c|c|c|c|c|c|c|c|c|c|c|c|}
\hline \multirow[t]{3}{*}{ Green area } & Total & 3,192 & 273 & 278 & 263 & 247 & 284 & 259 & 264 & 267 & 270 & 270 & 253 & 262 \\
\hline & Wastewater & 1,198 & 106 & 106 & 100 & 93 & 113 & 98 & 97 & 95 & 101 & 99 & 91 & 97 \\
\hline & Stormwater & 1,994 & 167 & 172 & 163 & 154 & 171 & 161 & 167 & 172 & 169 & 171 & 162 & 165 \\
\hline
\end{tabular}

Table 8. Comparison of the change in the sewage fee according to the phase

(Unit: million won)

\begin{tabular}{|c|c|c|c|c|c|c|c|c|c|c|c|c|}
\hline \multirow[t]{3}{*}{$\begin{array}{l}\text { By land use } \\
\text { area }\end{array}$} & \multirow[t]{3}{*}{$\begin{array}{l}\text { Number of lots to be } \\
\text { charged }\end{array}$} & \multicolumn{2}{|c|}{$\begin{array}{l}\text { Area to be charged } \\
(\mathbb{\nabla})^{\star \star}\end{array}$} & \multicolumn{3}{|c|}{ Annual average fee } & \multicolumn{6}{|c|}{ Change by phase } \\
\hline & & \multirow[t]{2}{*}{ Impervious } & \multirow[t]{2}{*}{ Total } & \multirow[t]{2}{*}{$\begin{array}{l}\text { Phase } \\
1\end{array}$} & \multirow[t]{2}{*}{$\begin{array}{l}\text { Phase } \\
2\end{array}$} & \multirow[t]{2}{*}{$\begin{array}{l}\text { Phase } \\
3\end{array}$} & \multicolumn{2}{|c|}{$\begin{array}{l}\text { Phase 2-Phase } \\
1\end{array}$} & \multicolumn{2}{|c|}{$\begin{array}{l}\text { Phase 3- } \\
\text { Phase } 2\end{array}$} & \multicolumn{2}{|c|}{$\begin{array}{l}\text { Phase 3-Phase } \\
1\end{array}$} \\
\hline & & & & & & & Amt & Ratio & Amt & Ratio & Amt & Ratio \\
\hline Total & 25,154 & 15.53 & 21.34 & 21,685 & 21,685 & 21,685 & - & - & - & - & - & - \\
\hline $\begin{array}{l}\text { Residential } \\
\text { area }\end{array}$ & 19,043 & 7.92 & 9.91 & 11,280 & 11,607 & 11,194 & 327 & 2.82 & -413 & -3.69 & -86 & -0.77 \\
\hline $\begin{array}{l}\text { Commercial } \\
\text { area }\end{array}$ & 4,312 & 1.21 & 1.31 & 5,191 & 3,902 & 3,793 & $-1,289$ & -33.05 & -109 & -2.87 & $-1,398$ & -36.87 \\
\hline Industrial area & 1,268 & 2.83 & 3.02 & 3,221 & 3,409 & 3,515 & 188 & 5.5 & 106 & 3.02 & 294 & 8.35 \\
\hline Green area & 531 & 3.57 & 7.11 & 1,996 & 2,771 & 3,192 & 775 & 27.96 & 421 & 13.19 & 1,196 & 37.46 \\
\hline
\end{tabular}

* Number of lots to be charged: When a building covers multiple lots, they are combined into one lot number by editing the serial cadastral map.

** Area to be charged = Total area of Bupyeong-gu - Area occupied by the municipality and central government (e.g., road, mountain, river)

\subsection{Results when applying the fee estimation scenario for an apartment complex while considering the number of households and the unit area type}

The sewage fee charged to the "Bugae $\mathrm{P}$ " apartment complex (1,102 households in total), the largest among the apartment complexes in Bupyeong-gu, was calculated for each phase. This apartment complex belongs to the type two general residential area when considering the land use areas. The total area was $56,823.8 \mathrm{~m}^{2}$, the impervious surface area was $35,079.9 \mathrm{~m}^{2}$, and the impervious surface ratio was approximately $61.7 \%$. The monthly average sewage fees that were charged to the total apartment complex were $8,741,013$ won in phase $1,7,926,900$ won in phase 2 , and 7,814,013 won in Phase 3 . As a result, the fee decreased by $10.6 \%$. The monthly average stormwater utility fee was 3,496,405 won in phase 1,2,682,292 won in phase 2, and 2,569,405 won in Phase 3 . As it went from phase 1 to phase 3 , it decreased by approximately $26.51 \%$ (Table 9 ).

Table 9. Calculation result of a large-scale apartment complex for the sewage fee according to the phase.

(Unit: 1,000 won)

\begin{tabular}{|c|c|c|c|c|c|c|c|c|c|c|c|c|c|c|c|}
\hline \multirow[t]{2}{*}{ Phase } & & \multicolumn{14}{|c|}{ Total sewage fee for an apartment complex } \\
\hline & & Total & Jan & Feb & Mar & Apr & May & Jun & Jul & Aug & Sep & Oct & Nov & Dec & Avg \\
\hline \multirow[t]{3}{*}{ Phase 1} & Total & 104,892 & 7,552 & 8,084 & 7,940 & 7,092 & 8,469 & 9,016 & 9,463 & 9,679 & 10,484 & 9,165 & 9,049 & 8,899 & 8,741 \\
\hline & Wastewater & 62,935 & 4,531 & 4,850 & 4,764 & 4,255 & 5,081 & 5,409 & 5,678 & 5,808 & 6,291 & 5,499 & 5,429 & 5,339 & 5,245 \\
\hline & Stormwater & 41,957 & 3,021 & 3,234 & 3,176 & 2,837 & 3,388 & 3,606 & 3,785 & 3,872 & 4,194 & 3,666 & 3,620 & 3,559 & 3,496 \\
\hline \multirow[t]{3}{*}{ Phase 2} & Total & 95,123 & 7,233 & 7,633 & 7,391 & 6,739 & 7,832 & 8,011 & 8,377 & 8,587 & 9,031 & 8,249 & 8,041 & 7,999 & 7,927 \\
\hline & Wastewater & 62,935 & 4,531 & 4,850 & 4,764 & 4,255 & 5,081 & 5,409 & 5,678 & 5,808 & 6,291 & 5,499 & 5,429 & 5,339 & 5,245 \\
\hline & Stormwater & 32,188 & 2,701 & 2,783 & 2,627 & 2,484 & 2,751 & 2,601 & 2,699 & 2,780 & 2,741 & 2,750 & 2,612 & 2,659 & 2,682 \\
\hline \multirow[t]{3}{*}{ Phase 3} & Total & 93,768 & 7,119 & 7,516 & 7,280 & 6,635 & 7,716 & 7,901 & 8,263 & 8,470 & 8,916 & 8,134 & 7,931 & 7,887 & 7,814 \\
\hline & Wastewater & 62,935 & 4,531 & 4,850 & 4,764 & 4,255 & 5,081 & 5,409 & 5,678 & 5,808 & 6,291 & 5,499 & 5,429 & 5,339 & 5,245 \\
\hline & Stormwater & 30,833 & 2,588 & 2,666 & 2,517 & 2,379 & 2,635 & 2,492 & 2,586 & 2,663 & 2,625 & 2,634 & 2,502 & 2,547 & 2,569 \\
\hline
\end{tabular}

In addition, phased fees were applied and compared while considering the unit area type of the households in the apartment complex. A higher fee was applied to the households with a larger unit area, even in the same apartment complex. The fees were distributed while considering the number of households 
in each unit area type. The total impervious surface area of the apartment complex was divided by the total number of unit areas $\left(1\right.$ pyeong $\left.\approx 3.3058 \mathrm{~m}^{2}\right)$ to calculate the impervious surface area per pyeong.

Responsible impervious surface area per pyeong $=0.856 \mathrm{~m}^{2} /$ pyeong

$$
\left(=35,079.9 \mathrm{~m}^{2} / 40,965 \text { pyeong }\right)
$$

The responsible impervious surface area per pyeong was determined to be $0.856 \mathrm{~m}^{2}$. When this value is multiplied by the number of pyeong in each household, the stormwater utility fee that is proportional to the impervious surface area for each household can be determined.

The sewage fees of the individual households by the unit area type were calculated while considering the impervious surface area per pyeong. In phase 1 , the monthly average sewage fee was calculated as 7,324 won (87,891 won/year) for 26 pyeong, 7,494 won (89,931 won/year) for 35 pyeong, 8,110 won ( 97,327 won/year) for 40 pyeong, and 10,140 won (121,686 won/year) for 60 pyeong. In phase 2, the monthly average sewage fee was calculated as 6,727 won (80,724 won/year) for 26 pyeong, 6,857 won (82,289 won/year) for 35 pyeong, 7,330 won (87,963 won/year) for 40 pyeong, and 8,887 won (106,650 won/year) for 60 pyeong. Finally, in phase 3 , the monthly average sewage fee was calculated as 6,644 won (79,730 won/year) for 26 pyeong, 6,769 won (81,229 won/year) for 35 pyeong, 7,222 won (86,229 won/year) for 40 pyeong, and 8,714 won (104,565 won/year) for 60 pyeong. The sewage fee increased with the number of pyeong in each household, and it decreased as the phase progressed. These fee calculations are possible because there are accurate statistics for the impervious surface areas. As the results show, the fees can be charged according to the contribution to the impervious surface; thus, they greatly contribute to a fair sewage fee system (Tables 10 and 11).

Table 10. Monthly sewage fee while considering the unit area type for a large apartment complex.

(Unit: 1,000 won) 


\begin{tabular}{|c|c|c|c|c|c|c|c|c|c|c|c|c|c|c|}
\hline \multirow[t]{2}{*}{ Phase } & & \multirow{2}{*}{$\begin{array}{l}\text { Unit } \\
\text { area }\end{array}$} & \multicolumn{12}{|c|}{ Monthly sewage fee by household } \\
\hline & & & $\begin{array}{l}\text { Monthly } \\
\text { Avg }\end{array}$ & Jan & Feb & Mar & Apr & May & Jun & Jul & Aug & Sep & Oct & Nov \\
\hline \multirow{9}{*}{$\begin{array}{l}\text { Phase } \\
1\end{array}$} & \multirow[t]{4}{*}{ Total } & 26 & 7,324 & 6,328 & 6,773 & 6,653 & 5,942 & 7,096 & 7,555 & 7,929 & 8,110 & 8,785 & 7,680 & 7,582 \\
\hline & & 35 & 7,494 & 6,475 & 6,930 & 6,807 & 6,080 & 7,261 & 7,730 & 8,113 & 8,299 & 8,989 & 7,858 & 7,758 \\
\hline & & 40 & 8,110 & 7,008 & 7,500 & 7,367 & 6,580 & 7,858 & 8,366 & 8,780 & 8,981 & 9,728 & 8,504 & 8,396 \\
\hline & & 60 & 10,140 & 8,761 & 9,378 & 9,211 & 8,227 & 9,825 & 10,459 & 10,978 & 11,229 & 12,163 & 10,633 & 10,498 \\
\hline & Wastewater & - & 4,759 & 4,112 & 4,401 & 4,323 & 3,861 & 4,611 & 4,909 & 5,152 & 5,270 & 5,708 & 4,990 & 4,927 \\
\hline & \multirow[t]{4}{*}{ Stormwater } & 26 & 2,565 & 2,216 & 2,372 & 2,330 & 2,081 & 2,485 & 2,646 & 2,777 & 2,840 & 3,077 & 2,690 & 2,655 \\
\hline & & 35 & 2,735 & 2,363 & 2,529 & 2,484 & 2,219 & 2,650 & 2,821 & 2,961 & 3,029 & 3,281 & 2,868 & 2,831 \\
\hline & & 40 & 3,351 & 2,896 & 3,099 & 3,044 & 2,719 & 3,247 & 3,457 & 3,628 & 3,711 & 4,020 & 3,514 & 3,469 \\
\hline & & 60 & 5,381 & 4,649 & 4,977 & 4,888 & 4,366 & 5,214 & 5,550 & 5,826 & 5,959 & 6,455 & 5,643 & 5,571 \\
\hline \multirow{9}{*}{$\begin{array}{l}\text { Phase } \\
2\end{array}$} & \multirow[t]{4}{*}{ Total } & 26 & 6,727 & 6,094 & 6,442 & 6,250 & 5,683 & 6,629 & 6,817 & 7,132 & 7,309 & 7,719 & 7,008 & 6,843 \\
\hline & & 35 & 6,857 & 6,225 & 6,578 & 6,378 & 5,804 & 6,763 & 6,944 & 7,263 & 7,444 & 7,852 & 7,141 & 6,970 \\
\hline & & 40 & 7,330 & 6,701 & 7,068 & 6,841 & 6,242 & 7,247 & 7,402 & 7,739 & 7,934 & 8,335 & 7,626 & 7,431 \\
\hline & & 60 & 8,887 & 8,270 & 8,684 & 8,366 & 7,684 & 8,844 & 8,912 & 9,306 & 9,548 & 9,926 & 9,223 & 8,947 \\
\hline & Wastewater & - & 4,759 & 4,112 & 4,401 & 4,323 & 3,861 & 4,611 & 4,909 & 5,152 & 5,270 & 5,708 & 4,990 & 4,927 \\
\hline & \multirow[t]{4}{*}{ Stormwater } & 26 & 1,968 & 1,982 & 2,041 & 1,927 & 1,822 & 2,018 & 1,908 & 1,980 & 2,039 & 2,011 & 2,018 & 1,916 \\
\hline & & 35 & 2,098 & 2,113 & 2,177 & 2,055 & 1,943 & 2,152 & 2,035 & 2,111 & 2,174 & 2,144 & 2,151 & 2,043 \\
\hline & & 40 & 2,571 & 2,589 & 2,667 & 2,518 & 2,381 & 2,636 & 2,493 & 2,587 & 2,664 & 2,627 & 2,636 & 2,504 \\
\hline & & 60 & 4,128 & 4,158 & 4,283 & 4,043 & 3,823 & 4,233 & 4,003 & 4,154 & 4,278 & 4,218 & 4,233 & 4,020 \\
\hline \multirow{9}{*}{$\begin{array}{l}\text { Phase } \\
3\end{array}$} & \multirow[t]{4}{*}{ Total } & 26 & 6,644 & 16,663 & 17,455 & 17,002 & 15,480 & 17,398 & 18,208 & 19,169 & 19,437 & 20,784 & 18,723 & 18,295 \\
\hline & & 35 & 6,769 & 16,939 & 17,738 & 17,268 & 15,731 & 17,660 & 18,479 & 19,459 & 19,725 & 21,085 & 19,013 & 18,566 \\
\hline & & 40 & 7,222 & 17,939 & 18,765 & 18,231 & 16,642 & 18,610 & 19,459 & 20,510 & 20,768 & 22,175 & 20,062 & 19,549 \\
\hline & & 60 & 8,714 & 21,235 & 22,149 & 21,402 & 19,640 & 21,739 & 22,688 & 23,973 & 24,204 & 25,766 & 23,518 & 22,789 \\
\hline & Wastewater & - & 4,759 & 12,498 & 13,179 & 12,995 & 11,692 & 13,443 & 14,128 & 14,793 & 15,095 & 16,246 & 14,356 & 14,201 \\
\hline & \multirow[t]{4}{*}{ Stormwater } & 26 & 1,885 & 1,898 & 1,956 & 1,846 & 1,746 & 1,933 & 1,828 & 1,897 & 1,953 & 1,926 & 1,933 & 1,836 \\
\hline & & 35 & 2,010 & 2,024 & 2,085 & 1,969 & 1,861 & 2,061 & 1,949 & 2,023 & 2,083 & 2,054 & 2,061 & 1,957 \\
\hline & & 40 & 2,463 & 2,480 & 2,555 & 2,412 & 2,281 & 2,525 & 2,388 & 2,478 & 2,552 & 2,516 & 2,525 & 2,398 \\
\hline & & 60 & 3,955 & 3,983 & 4,103 & 3,873 & 3,662 & 4,055 & 3,835 & 3,979 & 4,098 & 4,041 & 4,055 & 3,851 \\
\hline
\end{tabular}

Table 11. Phased sewage fee while considering the unit area type for a large apartment complex.

(Unit: 1,000 won)

\begin{tabular}{|c|c|c|c|c|c|c|c|c|c|c|c|c|}
\hline \multirow{3}{*}{$\begin{array}{l}\text { Unit } \\
\text { area } \\
\text { type }\end{array}$} & \multirow{3}{*}{$\begin{array}{l}\text { Number } \\
\text { of } \\
\text { buildings }\end{array}$} & \multirow{3}{*}{$\begin{array}{l}\text { Total } \\
\text { number of } \\
\text { households }\end{array}$} & \multirow{3}{*}{$\begin{array}{l}\text { Share } \\
(\%)\end{array}$} & \multirow{3}{*}{$\begin{array}{l}\text { Responsible } \\
\text { impervious } \\
\text { area by unit } \\
\text { area type } \\
(\Xi)^{\star \star}\end{array}$} & \multicolumn{8}{|c|}{ Annual total sewage fee by household } \\
\hline & & & & & \multicolumn{3}{|l|}{ Phase 1} & \multicolumn{3}{|l|}{ Phase 2} & \multicolumn{2}{|l|}{ Phase 3} \\
\hline & & & & & Total & Wastewater & $\begin{array}{l}\text { Storm } \\
\text { water }\end{array}$ & Total & Wastewater & $\begin{array}{l}\text { Storm } \\
\text { water }\end{array}$ & Total & Wastewatı \\
\hline 26 & 3 & 240 & 15.23 & 22.26 & 87,891 & 57,110 & 30,781 & 80,724 & 57,110 & 23,614 & 79,730 & 57,110 \\
\hline 35 & 3 & 303 & 25.89 & 29.97 & 89,931 & 57,110 & 32,821 & 82,289 & 57,110 & 25,179 & 81,229 & 57,110 \\
\hline 40 & 5 & 471 & 45.99 & 34.25 & 97,327 & 57,110 & 40,217 & 87,963 & 57,110 & 30,853 & 86,664 & 57,110 \\
\hline 60 & 1 & 88 & 12.89 & 51.38 & 121,686 & 57,110 & 64,576 & 106,650 & 57,110 & 49,540 & 104,565 & 57,110 \\
\hline
\end{tabular}

* Share: The ratio of the responsible area for all households for each unit area type with an impervious surface area that is charged

** Responsible impervious surface area by the unit area type $=$ (Total impervious surface area in the apartment complex / $\Sigma($ Unit area type $\times$ Number of households)) $\times$ Unit area type 


\section{Conclusions}

This study proposes a phased separate estimation scenario for wastewater and stormwater fees in order to create a stormwater utility fee system that is suitable for South Korea. This is achieved while considering the impervious surface area and the changes in the fees, which were compared by applying this scenario. To that end, a variety of overseas cases and domestic current systems were analyzed and discussed. In addition, the statistics for the impervious surface area of the optimal large-scale impervious surface map that was produced in a previous study were used. The impervious surface area based on the land use area and parcel was calculated with an overlap with the serial cadastral map, and the fees were calculated based on the water and sewage usage between January to December 2014 in Bupyeong-gu, Incheon. Finally, they were applied as a pilot to each land use area and an apartment complex, and the changes in the fees in each phase were compared.

The total sewage fee between January to December 2014 in Bupyeong-gu was determined to be 21,685,446,578 won(\$19.7 million USD). Under the assumption that the share of the stormwater utility fee was $40 \%$ of the total sewage fee and the total fee does not change, the stormwater utility fees in each phase were calculated. When the stormwater utility fees for each land use area were calculated, the fees of the residential area and commercial area decreased as the phase progressed, whereas the fees for the industrial area and green area increased. In particular, the stormwater utility fee for the residential area decreased by $1.9 \%$ in comparison to the existing fee. Since South Korea has many apartment complexes, the fees are expected to decrease even further when the number of households and the area unit type of the apartment complexes are considered. To verify these assumptions, a large-scale apartment complex was randomly selected and the total sewage fee charged to the apartment complex was calculated. Then, the fees were calculated based on the impervious surface area in the parcel while considering the number of households and the unit area type. It was determined that for a large-scale apartment complex with a large pervious landscape area and a large number of households, the stormwater utility fee decreased by approximately $26.5 \%$ in comparison to the existing fee. This study verified the possibility of estimating the stormwater utility fee by using an impervious surface map that was produced in a previous study and the impervious surface ratio calculation method.

In the future, for the proper management of non-point sources and stormwater runoffs, a stormwater utility fee system that considers the impervious surface area and is appropriate for South Korea needs to be introduced and operated. However, in order to apply the stormwater utility fee, thorough preparations are required, such as discussing financing and the responsibilities of the public and private sectors for stormwater management. The reason for this is that when a stormwater utility fee is collected without the citizens' understanding, the citizens may provide resistance. As a result, it is necessary to improve the water environment by using the necessary financial resources and actively investing in water environment management as well as the implementation of a stormwater utility fee system. Furthermore, this system should be promoted based on the basic fee estimation method after the cost is allocated and calculated according to reasonable standards and grounds for each municipality. In addition, it needs to take into account the future impervious surface area management cost, the capacity to bear the cost, and the property value.

\section{Declarations}

Funding: (information that explains whether and by whom the research was supported)

- Not applicable

Availability of data and material: (data transparency)

- Not applicable

Code availability: (software application or custom code)

- Not applicable

Ethical Approval Not Applicable

Consent to Participate Not Applicable

Consent to Publish Not Applicable

Conflicts of interest/Competing interests The authors declare no conflict of interest.

\section{References}

1. Bonnaffon H (2011) Local Stormwater Fees and Taxes: Results of the Sept. 2010 Survey. Chesapeake Bay and Water Resources Policy Committee (CBPC) Meeting, Washington D.C, USA, pp 1-17

2. Che W, Zhao Y, Yang Z, Li J, Shi M (2014) Integral stormwater management master plan and design in an ecological community. J Environ Sci 26(9):1818-1823

3. Crockett CS (2010) Parcel Based Billing for Stormwater. ASCE Philadelphia Section, Philadelphia, USA, pp 1-35

4. Dietz ME (2007) Low Impact Development Practices: A Review of Current Research and Recommendations for Future Directions. Water Air Soil Poll 186:351-363

5. Graham S, Schempp A, Troell J (2011) Regulating Nonpoint Source Water Pollution in a Federal Government: Four Case Studies. Int J Water Resour D 27(1):53-69

Page 13/16 
6. Kang JE, Lee MJ, Koo YS, Cho YH (2014) Development and Application of Green Infrastructure Planning Framework for Improving Urban Water Cycle. Korea Environment Institute 13(3):43-73 [Korean literature]

7. Kim KH, Stephen JV, Paul MH, Peter GT, Jeffrey P (1993) Urban Non-point-source Pollution Assessment Using a Geographical Information System. J Environ Manage 39(3):157-170

8. Kim KH, Choi JY, Lee CY, Park YG, Lee SJ, Ryu JH, Choi YG, Kwak GH, Lee GH, Oh SG, Hwang SH, Lee YJ, Park JY, Yoo SY (2015) The improvement plans for levying the sewerage fee considering land cover and stormwater runoff. Korea Environmental Industry \& Technology Institute (KEITI), Publication no. 2013000200001, pp 132-133 [Korean literature]

9. Kwon KH, Hur OK (2010) A measure for improvement of legal fairness by sewage charge: Introduction of German separate sewage charge system as a case study. Korea Research Institute for Local Administration 24(4):293-318 [Korean literature]

10. Lee CY, Kim KH, Kwak GH, Oh SK (2014) A Study on the Development of GIS-based Updating Methodology of Landcover Maps at Intermediate Level for Managing Nonpoint Source Pollutants. Korea Water Congress 2014, Korean Society on Water Environment and Korean Society of Water and Wastewater, pp 66-67 [Korean literature]

11. Lee CY, Kim KH, Lee H (2018a) GIS-based optimal impervious surface map generation using various spatial data for urban nonpoint source management. J Environ Manage 206:587-601

12. Lee CY (2018b) Development of a GIS-based Impervious Surface Ratio Estimation Methodology for Evaluating Water Cycle Soundness. Ph. D. Dissertation, Inha University, Incheon, S. Korea [Korean literature]

13. Ministry of Environment (MOE) (2012) Study on the Introduction of Rainwater Pollution Fee for the Management of Non-point Source Pollution. Ministry of Environment (MOE), pp. 1-8 [Korean literature]

14. Ministry of Environment (MOE) (2018) Framework Act on Water Management, Ministry of Environment (MOE), pp. 22-23 [Korean literature]

15. Parikh P, Taylor MA, Hoagland T, Thurston H, Shuster W (2005) Application of Market Mechanisms and Incentives to Reduce Stormwater Runoff: An Integrated Hydrologic, Economic and Legal Approach. Environ Sci Policy 8(2):133-144

16. Roy AH, Wenger SJ, Fletcher TD, Walsh CJ, Ladson AR, Shuster WD, Thurston HW, Brown RR (2008) Impediments and Solutions to Sustainable, Watershed-Scale Urban Stormwater Management: Lessons from Australia and the United States. Environ Manage 42(2):344-359

17. US EPA (2009) Funding Stormwater Programs. EPA-901-F-09-004, EPA National Pollution Discharge Elimination System (NPDES)

18. Yang HK (2006) Runoff Characteristics of Non-Point Source Pollutants in Storm Event: Case Study on the Upstream and Downstream of Kokseong River. The Korean Association of Geographic Information Studies 41(4):418-419 [Korean literature]

\section{Figures}

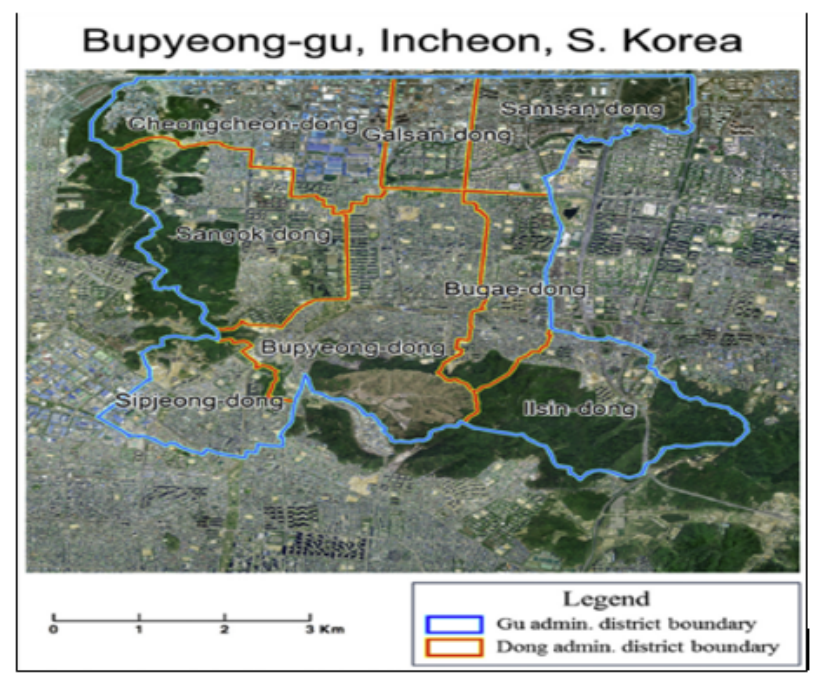

\section{Figure 1}

Study area (Bupyeong-gu, Incheon) Note: The designations employed and the presentation of the material on this map do not imply the expression of any opinion whatsoever on the part of Research Square concerning the legal status of any country, territory, city or area or of its authorities, or concerning the delimitation of its frontiers or boundaries. This map has been provided by the authors. 


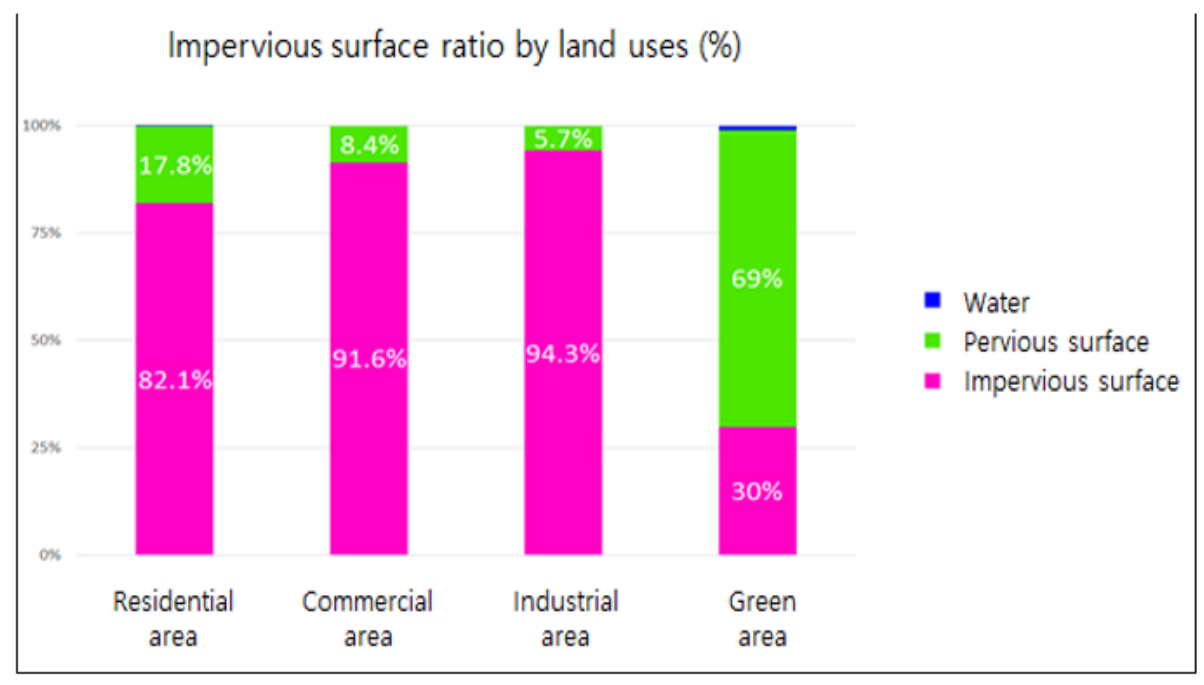

Figure 2

Estimation result of the impervious surface ratio according to the land use area
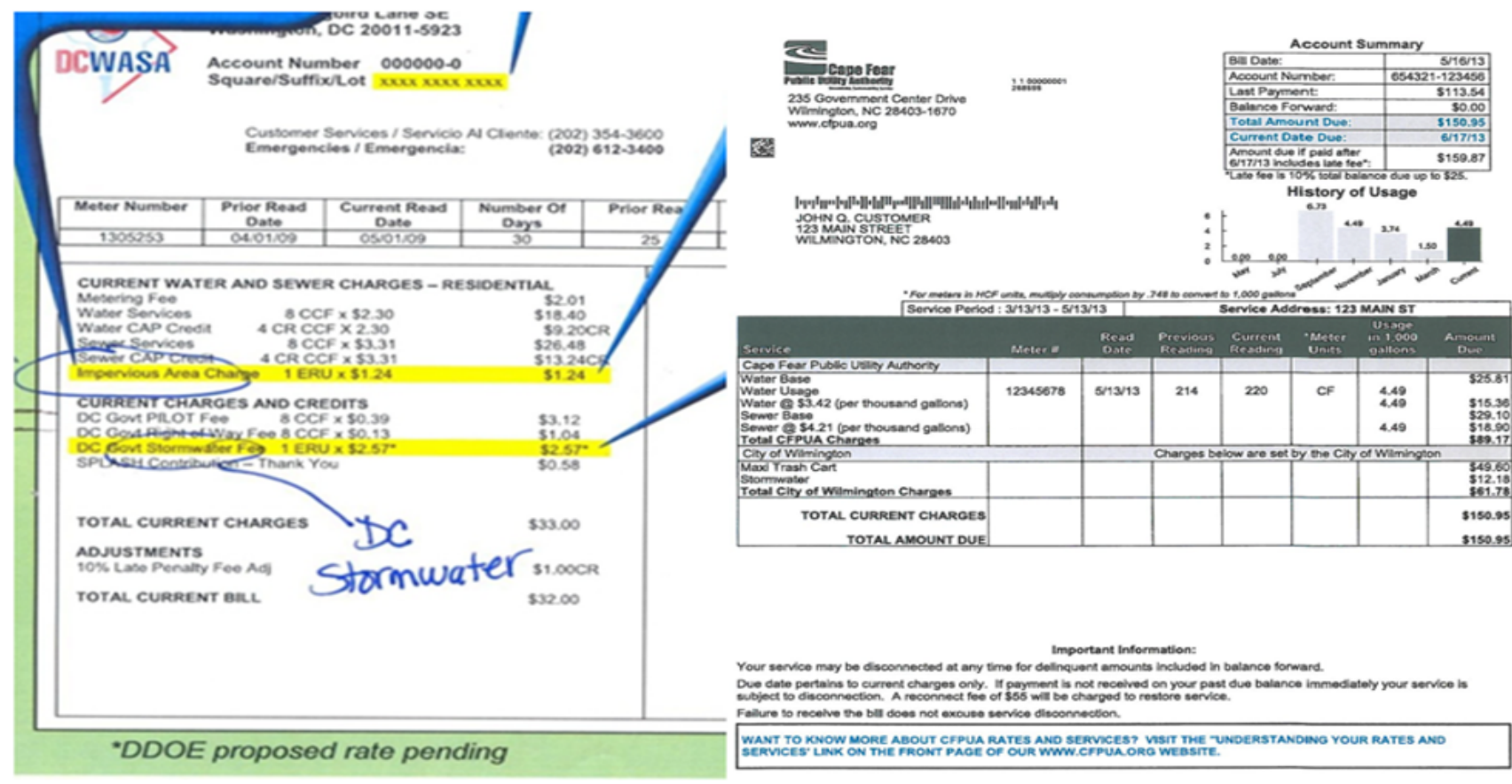

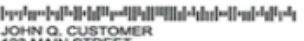

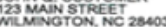

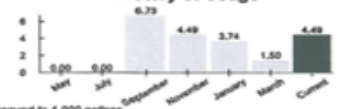

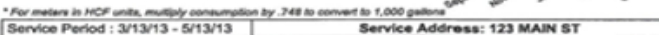

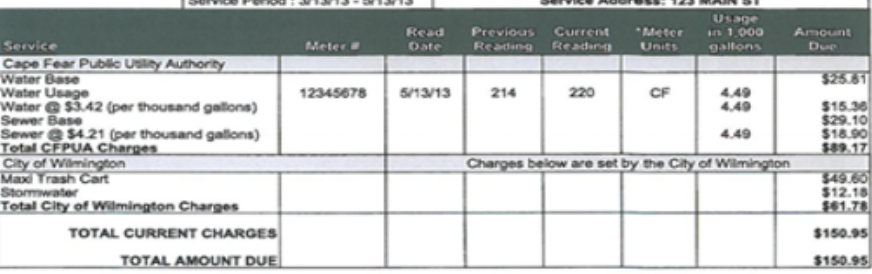

Your senvice may be discomected at any time for dethquert amounts included in batiance formard.

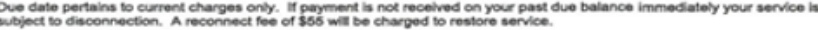

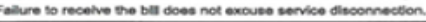

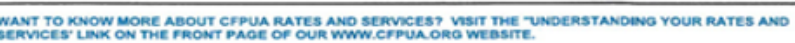

Figure 3

Stormwater utility fee combined in a water bill (Washington D.C., USA)

\begin{tabular}{|c|c|c|c|c|}
\hline $\begin{array}{c}\text { Collect the } \\
\text { monthly water } \\
\text { and sewage usage } \\
\text { statistics and } \\
\text { hydrant spatial } \\
\text { data }\end{array}$ & $\begin{array}{c}\text { Inspect and process } \\
\text { the data } \\
\text { (Check omissions } \\
\text { and integrate the lot } \\
\text { numbers) }\end{array}$ & $\begin{array}{l}\text { Calculate the } \\
\text { water and sewage } \\
\text { fees by applying } \\
\text { the rate table }\end{array}$ & $\begin{array}{l}\text { Define and apply } \\
\text { the phased fee } \\
\text { calculation } \\
\text { scenario }\end{array}$ & $\begin{array}{l}\text { Examine the } \\
\text { change in the } \\
\text { fees for the } \\
\text { apartment } \\
\text { complex while } \\
\text { considering the } \\
\text { number of } \\
\text { households and } \\
\text { the unit area size }\end{array}$ \\
\hline
\end{tabular}

Figure 4 
Simulated calculation process of the stormwater utility fee

Page 16/16 